\title{
THE RELATIONSHIPBETWEEN SEXUAL SATISFACTION AND MARITAL COMMITMENT AMONG MARRIED WOMEN IN IRAN
}

\author{
A RELAÇ̃̃O ENTRE SATISFAÇÃO SEXUAL E COMPROMISSO MARITAL ENTRE MULHERES CASADAS NO \\ $\operatorname{IR} \tilde{A}$
}

\begin{abstract}
Sexual satisfaction is one of the factors affecting interpersonal relationships. The purpose of this research was to determine the relationship between sexual satisfaction and marital commitment among married women in Neyshabur, Iran in 2019. This cross-sectional study was conducted on 330 married women. The instruments used were Larsson sexual satisfaction and marital commitment Adams questionnaire. The collected data were entered in to SPSS software with version 20 and using descriptive statistic methods, The Pearson's correlation analysis and ANOVA tests were used. The mean age of women was 23.92 23.96 years. In addition, $7(2.12 \%), 37(11.21 \%), 148(44.84 \%)$ and $138(41.81 \%)$ of women showed zero, low, moderate, and high levels of sexual satisfaction. Marital commitment was positively correlated with the overall sexual satisfaction $(\mathrm{r}=$ $0.67, \mathrm{P}<0.001)$. Moreover, marital commitment was associated with High sexual satisfaction $\mathrm{n}(\mathrm{r}=.69, \mathrm{p}<.001)$, Medium sexual satisfaction $(\mathrm{r}=.52, \mathrm{p}<.001)$, Law of sexual satisfaction $(\mathrm{r}=.39, \mathrm{p}<.001)$ Lack of sexual satisfaction $(\mathrm{r}=.19, \mathrm{p}<.001)$, subscales of sexual satisfaction. Women with shorter marriage levels had higher sexual satisfaction and marital commitment. Therefore, health planners should adopt strategies to increase sexual satisfaction, marital commitment in women with longer marriage levels.
\end{abstract}

Keywords: Women. Sexual satisfaction. Marital commitment. Iran.

\section{RESUMO}

A satisfação sexual é um dos fatores que afetam as relações interpessoais. O objetivo desta pesquisa foi determinar a relação entre a satisfação sexual e o compromisso marital entre mulheres casadas em Neyshabur, Irã, em 2019. Este estudo transversal foi realizado com 330 mulheres casadas. Os instrumentos utilizados foram o questionário de Adams de satisfação sexual e compromisso

Zeinab Jalambadani

Department of public health, Neyshabur University of Medical Sciences, Neyshabur, Iran. (Corresponding author) E-mail: jalambadaniz@gmail.com, jalambadaniz@nums.ac.ir

Ahmad Sharifnezhad

Assistant Professor of Health Psychology, Neyshabur University of Medical Sciences,

Neyshabur, Iran. E-mail: sharifna1@nums.ac.ir

Sara Sadeghi

Student Research Committee, Neyshabur University of Medical Sciences, Neyshabur, Iran. E-mail: jalambadaniz@yahoo.com 
conjugal de Larsson. Os dados coletados foram inseridos no software SPSS com a versão 20 e, por meio de métodos estatísticos descritivos, foram utilizados a análise de correlação de Pearson e testes ANOVA. A média de idade das mulheres foi $23,92 \pm 3,96$ anos. Além disso, 7 (2,12\%), 37 (11,21\%), $148(44,84 \%)$ e $138(41,81 \%)$ das mulheres apresentaram níveis zero, baixo, moderado e alto de satisfação sexual. $\mathrm{O}$ compromisso conjugal foi positivamente correlacionado com a satisfação sexual geral ( $\mathrm{r}=0,67, \mathrm{P}<0,001)$. Além disso, o compromisso conjugal foi associado a alta satisfação sexual n $(\mathrm{r}=0,69, \mathrm{p}<0,001)$, satisfação sexual média $(\mathrm{r}=0,52, \mathrm{p}<0,001)$, lei da satisfação sexual $(\mathrm{r}=0,39, \mathrm{p}<$.oo1) Falta de satisfação sexual $(\mathrm{r}=.19, \mathrm{p}$ $<.001$ ), subescalas de satisfação sexual. Mulheres com menos tempo de casamento apresentaram maior satisfação sexual e compromisso matrimonial. Portanto, os planejadores de saúde devem adotar estratégias para aumentar a satisfação sexual, o compromisso conjugal para mulheres em casamentos de longo prazo.

Palavras-chave: Mulheres. Satisfação sexual. Compromisso conjugal. Irã.

\section{Introduction}

Sexual satisfaction exists at marital status conforms of the needed circumstance. Assuming that couples camwood enhance the level about satisfaction done marital life, they will ensure those crews (Træen et al., 2019). The definition of sexual satisfaction proposed by Lawrence and Byes (1995) "an effective response arising from one's subjective evaluation of the positive and negative dimensions associated with one's sexual relationship" has been adopted because it includes both affective and cognitive component as is typical in psychological research of constructs related to satisfaction and well-being (Rehman, Fallis, \& Byers, 2013). Iranian masters accept that 50 to 60 percent about divorces are initiated by sexual problems, including sexual dissatisfaction (Musavi, Fatehizade, \& Jazayeri, 2019). Marital commitment is strongest and the vast majority stable foreseeing component from claiming personal satisfaction and soundness of a marriage (Bloom, 2015). When couples require whole deal perspectives also they settle on sacrifices with the individual relationship. They settle on every attempt ought to stay with likewise strengthen their bonds also they remain wedded in reality setting of this purpose when fizzles (Harmon, 2005). There might be a join between higher levels of matrimonial commitment in addition, extra need expression, higher flexible additionally reliability to matrimonial relationship, better issue comprehending abilities in addition matrimonial satisfaction(Masters, 2008) additionally more levels matrimonial guarantee are joined with matrimonial exhaustion. It seems to make that commitment should existence accomplice also furthermore guarantee will association about might make way (Lambert \& Dollahite, 2008). It seems that commitment will friend also commitment with station form will be vital (Lambert \& Dollahite, 20o8). Despite several investigations compelling reason 
has been guided to Iranian amount to illustrate. Side of the point toward purpose lion's sharing of the information concerning matrimonial dissatisfaction, sexual frustration. Underpins the those larger part purpose behind matrimonial frustration done Iran (70\%) (Rahmani, Alahgholi, \& Khuee, 2009). This research might make supportive will distinguish a few factors influencing around sexual satisfaction. Moving forward, this consciousness might convince social insurance suppliers to create context-based. Project to tending to conjugal satisfaction, thereby, higher conjugal fulfillment might lead with crew dependability.

The purpose of this research was to determine the relationship between sexual satisfaction and marital commitment among married women in Neyshabur, Iran in 2019 .

\section{Methodology}

This cross-sectional study was conducted in 2019, among married women in Neyshabur, Iran. The patient information was anonymized and de-identified prior to analysis.

The formula was utilized for the calculation of the sample size, in which the power of study considered was $80 \%$ and $\alpha=0.05 \%$ (Abedi, Afrazeh, Javadifar, \& Saki, 2015). According to the formula, the sample size was 330.

$$
\begin{aligned}
& n=\frac{\left(Z 1-\frac{\alpha}{2}\right)^{2}(P \times q)}{(d)^{2}} \\
& n=\frac{\left(Z 1-\frac{\alpha}{2}\right)^{2}(P \times q)}{(d)^{2}}=\frac{0.895}{0.003} \sim 330
\end{aligned}
$$

$\mathrm{P}=0.63$

$\mathrm{Q}=0.37$

$\mathrm{d}=0.1 \times \mathrm{P}$

The samples were enrolled in the study, according to the inclusion criteria: age of adult females between 18-49 years, no pregnant, no breastfeeding and literate with Iranian nationality, no chronic conditions like mental illness, high blood pressure, diabetes, cardiovascular problems, chronic vaginal infection, renal disorders, no account of smoking, alcohol, and antidepressants, and no history of stressful events like death of relatives and divorce in the past half dozen months. The women were explained the study and informed consent was received from them. 


\section{Instruments}

For quantitative analysis of data, obtaining information within the framework of the subject, gathering data related to the variables of the field and evaluating marital commitment Adams (1997) standard marital commitment questionnaire was applied. This questionnaire covers three aspects of personal commitment (questions -4-8-10-11-14-16-18-21-24-25-27-28-31-32-35-36-38-44), moral commitment (questions -6-9-13-20-22-23-26-29-30-34-37-41) and structural commitment (questions -5-7-1215-17-19-33-39-40-42-43) and consists of 44 questions. 5-level Likert spectrum is used to answer the questions, with 1 being very little and 5 being very much. Most of the items of the questionnaire are scored directly, but questions (11 - 12- 16-23-28-29-3032-34-35-36-38) are scored in reverse order. The general scoring range is between 1 and 172 and the higher scores show higher levels of marital commitment.

The sexual satisfaction of the samples was measured by the Larsson sexual satisfaction questionnaire, which has been proven to be of scientific validity and reliability. The questionnaire contains 25 questions with quintuple-choice answers based on a Likert scale of 1-5 scores. Scores of 25-50, 51-75, 76-10o, and 101-125 denote zero, low, intermediate, and high sexual satisfaction levels, respectively(Larson, Anderson, Holman, \& Niemann, 1998).

The validity and reliability for questionnaires were directed in Iran(Bahrami, Sharif Nia, Soliemani, \& Haghdoost, 2016; Tahmasebi \& Ahmadi, 2015)

\section{Statistical analysis}

For the statistical analyses, SPSS 20 (SPSS Inc., Chicago, IL, USA) was utilized. The data were analyzed using descriptive statistics methods including frequency, percentage, mean, standard deviation scores. The Pearson's correlation analysis and ANOVA tests were used to determine the relation between sexual satisfactions and marital commitment subscales scores. The reliability was evaluated using the Cronbach's alpha reliability coefficient. The statistical significance was $\mathrm{P}<0.05$.

\section{Results}

The average age of women was $23.92 \pm 3.96$ years. Most of the study population $(62.12 \%)$ were in the age group of 18 - 49 years. In terms of working status, the majority of the women (95.15\%) were housewife. The marital commitment average scores according to age groups $(\mathrm{p}=. \mathrm{ol})$, education level $(\mathrm{p}<0 \mathrm{0o1})$, working status $(\mathrm{p}<.001)$, marital status $(\mathrm{p}<.001)$, the income perception $(\mathrm{p}=. \mathrm{ol})$, family type $(\mathrm{p}=0.16)$ husband's education level $(\mathrm{p}=. \mathrm{ol})$ of women were compared and the differences 
between groups were statistically significant. Sexual satisfaction average scores according to age groups $(\mathrm{p}=. \mathrm{o1})$, educational level $(\mathrm{p}<.001)$, working status $(\mathrm{p}<.001)$, marital status $(\mathrm{p}<.001)$, family type $(\mathrm{p}=.01)$, husband's education level $(\mathrm{p}<.01)$ were compared and the differences between groups were statistically significant (Table 1). In addition, $7(2.12 \%), 37(11.21 \%), 148(44.84 \%)$ and $138(41.81 \%)$ of women showed zero, low, moderate, and high levels of sexual satisfaction. The total scores of the marital commitment ranged from 1 to 172 , with a mean of 136.64 (SD =6.90). Sexual satisfaction was positively correlated with the overall marital commitment $(\mathrm{r}=0.67$; $\mathrm{P}<0.001)$.

Moreover, marital commitment was associated with High sexual satisfaction $\mathrm{n}(\mathrm{r}=.69, \mathrm{p}<.001)$, Medium sexual satisfaction $(\mathrm{r}=.52, \mathrm{p}<.001)$, Law of sexual satisfaction $(\mathrm{r}=.39, \mathrm{p}<.001)$ Lack of sexual satisfaction $(\mathrm{r}=.19, \mathrm{p}<.001)$, subscales of sexual satisfaction(Table 1 ).

Table 2 contains the results of the ANOVA test and describes whether our four groups created on the basis of their sexual satisfaction score differed statistically significantly from each other. According to the average values recorded, this Marital commitment was adopted significantly more often by women with High sexual satisfaction scores than women with Lack, low and medium sexual satisfaction scores.

\section{Discussion}

This study aimed to investigate the relationship between sexual satisfaction with marital commitment among married women in Neyshabur, Iran in 2019. The taboos of sexual issues in Iran as well as cultural, social, and educational differences prevent women from easily raising their sexual dissatisfaction issues, which explain the discrepancy between statistics on disturbed sexual satisfaction in Iran and other countries.

The results of the ANOVA test showed that high sexual dissatisfaction was higher in women with higher marital commitment. Shackelford TK also demonstrated significant relationships between sexual satisfaction with all aspects of marital commitment(Muehrer, Keller, Powwattana, \& Pornchaikate, 2006). Muehrer RJ et al., have achieved the same results as well(Jamali, Poornowrooz, Mosallanezhad, \& Alborzi, 2018). A study by Olson DH showed that marital dissatisfaction in individual with higher sexual satisfaction higher than normal people(Bodenmann, Atkins, Schär, \& Poffet, 2010). All of the above studies are in line with present findings.

The results showed significant relationships between sexual satisfaction and marital commitment with couples' education levels. The relationship between sexual dysfunction and low educational level was highlighted in various studies(Jamali, Alborzi, Javadpour, Haghbeen, \& Mosallanekhad, 2018; Jamali, Zarei, \& Jahromi, 
2014) and it is considered as one of the risk factors for increased sexual dysfunction. This finding is similar to that of the Nobre PJ et al (Nobre \& Pinto-Gouveia, 2006). It seems that educated people are more engaged in studying and thinking, hence, they can easily look for solutions to their problems resulting in enhanced marital commitment and consequently improved sexual satisfaction.

The results of this study signifies the relationship between sexual satisfaction and income, as was pointed out by Zincir H et al (Zincir, Özkan, Erten, \& Sevĭ̆ 2011). Ramezani $\mathrm{M}$ et al., also reported a high chance of dissatisfaction event in low-income spouses suggesting the impact of the economic situation on sexual satisfaction(Ramezani, Dolatian, Shams, \& Alavi, 2012). Apparently, job security and consequently improvements in the family's welfare and economic security can reduce economic-psychosocial stresses on the person and raise the satisfaction of marital relationship between couples.

These findings could suggest that women with high sexual satisfaction have a high marital commitment. The sexual relationship of spouses is a twoway process that is any disruptions in it can be a source of problems in family center. Problems with issues sexuality, such as lack of tenderness, disability, early ejaculation, maybe. Because of fear and anxiety, shame and embarrassment or feeling ineffective is hidden and not expressed, and in many cases it is late problems may be associated with symptoms and other complications like physical discomfort, depression and dissatisfaction with life Marriage and marital noncommittal and marital life up. The borderlines between family and divorce persist.

\section{Conclusion}

Considering the importance of sexual satisfaction in the family and the impacts on marital commitment and satisfaction of couples, health policy makers and family counselors should provide women with training strategies, so that they can take a step forward towards safe fertility. One of the strengths of this study is that women of reproductive ages that were not pregnant, in menopause or lactating period were examined, because these situations could have different effects on sexual function. Therefore, it is suggested that effects of stress on sexual function in the mentioned groups can be studied. This study was conducted only on women referred to public health clinics in Iran, so the results may not represent the entire population. Besides, because of the cultural and religious limitations in our society, people may not be able to speak easily about their sexual issues, so the potential insecurity of some people in expressing explicitly their issues was a limitation. 


\section{References}

Abedi, P., Afrazeh, M., Javadifar, N., \& Saki, A. (2015). The relation between stress and sexual function and satisfaction in reproductive-age women in Iran: a cross-sectional study. Journal of sex \& marital therapy, 41(4), 384-390.

Bahrami, N., Sharif Nia, H., Soliemani, M. A., \& Haghdoost, A. A. (2016). Validity and reliability of the persian version of Larson sexual satisfaction_questionnaire in couples. Journal of Kerman University of Medical Sciences, 23(3), 344-356.

Bloom, A. (2015). Explaining Relationship Satisfaction: Attachment, Technology Use, and Sexual Satisfaction in Long-Distance Relationships. (Doctor of Philosophy), Purdue University,

Bodenmann, G., Atkins, D. C., Schär, M., \& Poffet, V. (2010). The association between daily stress and sexual activity. Journal of Family Psychology, 24(3), 271.

Harmon, D. K. (2005). Black men and marriage: The impact of spirituality, religiosity, and marital commitment on marital satisfaction. The University of Alabama, ProQuest Dissertations Publishing: The University of Alabama.

Jamali, S., Alborzi, M., Javadpour, S., Haghbeen, M., \& Mosallanekhad, Z. (2018). A Study of Men's Sexuality and their Attitude during their Wives' Pregnancy. JOURNAL OF CLINICAL AND DIAGNOSTIC RESEARCH, 12(5), QC24-QC28.

Jamali, S., Poornowrooz, N., Mosallanezhad, Z., \& Alborzi, M. (2018). Correlation Between Sexual Satisfaction and Self-Esteem and Stress in Women of Reproductive Age. Journal of Clinical \& Diagnostic Research, $12(10)$.

Jamali, S., Zarei, H., \& Jahromi, A. R. (2014). The relationship between body mass index and sexual function in infertile women: A cross-sectional survey. Iranian journal of reproductive medicine, $12(3), 189$.

Lambert, N. M., \& Dollahite, D. C. (2008). The threefold cord: Marital commitment in religious couples. Journal of Family Issues, 29(5), 592-614.

Larson, J. H., Anderson, S. M., Holman, T. B., \& Niemann, B. K. (1998). A longitudinal study of the effects of premarital communication, relationship stability, and selfesteem on sexual satisfaction in the first year of marriage. Journal of sex $\mathcal{E}$ marital therapy, 24(3), 193-206.

Masters, A. (2008). Marriage, commitment and divorce in a matching model with differential aging. Review of Economic Dynamics, 11(3), 614-628. 
Muehrer, R. J., Keller, M. L., Powwattana, A., \& Pornchaikate, A. (2006). Sexuality among women recipients of a pancreas and kidney transplant. Western journal of nursing research, 28(2), 137-150.

Musavi, S., Fatehizade, M., \& Jazayeri, R. (2019). Sexual Dynamics of Iranian Remarried Women in Blended Families: A Qualitative Study on Remarried Women's Life. Journal of Divorce \& Remarriage, 6o(5), 333-345.

Nobre, P. J., \& Pinto-Gouveia, J. (2006). Dysfunctional sexual beliefs as vulnerability factors for sexual dysfunction. Journal of sex research, 43(1), 68-75.

Rahmani, A., Alahgholi, L., \& Khuee, E. M. (2009). P511 How does sexual satisfaction relate to marital satisfaction among Iranians? International Journal of Gynecology $\mathcal{E}$ Obstetrics, 107(S2).

Ramezani, N., Dolatian, M., Shams, J., \& Alavi, H. (2012). The relationship between self-esteem and sexual dysfunction and satisfaction in women. Journal of Arak University of Medical Sciences, 14(6), 57-65.

Rehman, U. S., Fallis, E., \& Byers, E. S. (2013). Sexual satisfaction in heterosexual women. An essential handbook of women's sexuality, 1, 25-45.

Tahmasebi, M., \& Ahmadi, E. (2015). The relationship between marital conflict and marital commitment of married couples in Ayatollah Amoli Azad University. International Journal of Humanities Cultural, 2(3), 1065-1075.

Træen, B., Štulhofer, A., Janssen, E., Carvalheira, A. A., Hald, G. M., Lange, T., \& Graham, C. (2019). Sexual activity and sexual satisfaction among older adults in four European countries. Archives of sexual behavior, 48(3), 815-829.

Zincir, H., Özkan, F., Erten, Z. K., \& Seviğ, E. Ü. (2011). Sexual Lives and Family Function of Women with Family Member with Disability: Educational Status and Income Level. Sexuality and Disability, 29(3), 197. 
Table 1. Differences of marital commitment and Sexual satisfaction scores according to socio-demographic variables of women $(n=330)$

\begin{tabular}{|c|c|c|c|c|c|c|}
\hline \multirow{2}{*}{\multicolumn{2}{|c|}{ Variable }} & \multirow[t]{2}{*}{ Number } & \multirow[t]{2}{*}{ Percent } & $\begin{array}{l}\text { marital } \\
\text { commitment } \\
\text { Total }\end{array}$ & \multirow[t]{2}{*}{ pvalue } & \multirow{2}{*}{$\begin{array}{l}\text { Sexual } \\
\text { satisfaction } \\
\text { Total } \\
\text { mean } \pm \text { SD }\end{array}$} \\
\hline & & & & mean \pm SD & & \\
\hline \multirow[t]{3}{*}{ Age (year) } & $18-28$ & 205 & 62.12 & $170.65 \pm 25.87$ & \multirow[t]{3}{*}{$\mathbf{P}=.01^{*}$} & $110.65 \pm 15.86$ \\
\hline & $29-39$ & 81 & 24.55 & $165.98 \pm 20.75$ & & $90.65 \pm 11.89$ \\
\hline & $40-50$ & 44 & $13 \cdot 33$ & $160.88 \pm 20.75$ & & $99.45 \pm 12.85$ \\
\hline \multirow[t]{3}{*}{ Family type } & Nucleus family & 207 & 62.73 & $160.68 \pm 21.75$ & \multirow[t]{3}{*}{$P=.016^{*}$} & $112.85 \pm 10.86$ \\
\hline & $\begin{array}{l}\text { single child } \\
\text { family }\end{array}$ & 63 & 19.09 & $162.58 \pm 12.75$ & & $100.65 \pm 11.89$ \\
\hline & 2 or more & 50 & 15.15 & $165.48 \pm 22.75$ & & $105.45 \pm 12.85$ \\
\hline \multirow{3}{*}{$\begin{array}{l}\text { Income } \\
\text { perception }\end{array}$} & Bad & 20 & 6.06 & $152.38 \pm 12.545$ & \multirow[t]{3}{*}{$\mathbf{P}=.01^{*}$} & $90.65 \pm 10.56$ \\
\hline & Middle & 250 & $75 \cdot 75$ & $169.88 \pm 13.45$ & & $98.55 \pm 10.89$ \\
\hline & Good & 60 & 18.18 & $160.78 \pm 11.75$ & & $110.45 \pm 12.85$ \\
\hline \multirow{3}{*}{$\begin{array}{l}\text { Working } \\
\text { status }\end{array}$} & Housewife & 314 & 95.15 & $168.67 \pm 12.75$ & \multirow[t]{3}{*}{$\mathbf{P}<.001^{* *}$} & $111.65 \pm 11.76$ \\
\hline & Officer & 10 & 3.03 & $160.85 \pm 11.45$ & & $90.64 \pm 10.89$ \\
\hline & Retired & 6 & 1.81 & $162.58 \pm 10.65$ & & $99.25 \pm 11.75$ \\
\hline \multirow{5}{*}{$\begin{array}{l}\text { Education } \\
\text { level }\end{array}$} & Illiterate & 30 & 9.09 & $168.68 \pm 12.15$ & \multirow[t]{5}{*}{$\mathbf{P}<.001^{* *}$} & $99.35 \pm 12.86$ \\
\hline & Elementary & 195 & 59.09 & $166.99 \pm 10.15$ & & $92.65 \pm 11.89$ \\
\hline & Middle school & 10 & 3.03 & $162.68 \pm 14.55$ & & $88.45 \pm 12.85$ \\
\hline & High school & 80 & 24.24 & $162.57 \pm 11.45$ & & $90.65 \pm 14.86$ \\
\hline & University & 15 & $4 \cdot 54$ & $162.78 \pm 11.55$ & & $100.65 \pm 11.89$ \\
\hline \multirow{5}{*}{$\begin{array}{l}\text { Husband } \\
\text { education } \\
\text { status }\end{array}$} & Illiterate & 10 & 3.03 & $169.98 \pm 12.25$ & \multirow[t]{5}{*}{$\mathbf{P}<.0011^{* *}$} & $91.45 \pm 12.85$ \\
\hline & Elementary & 70 & 21.21 & $168.66 \pm 12.85$ & & $92.65 \pm 10.86$ \\
\hline & Middle school & 90 & 27.27 & $164.58 \pm 11.65$ & & $80.65 \pm 11.89$ \\
\hline & High school & 140 & 42.42 & $162.77 \pm 11.75$ & & $95.45 \pm 12.85$ \\
\hline & University & 20 & 6.06 & $162.88 \pm 11.75$ & & $110.25 \pm 11.46$ \\
\hline \multirow{3}{*}{$\begin{array}{l}\text { Duration of } \\
\text { marriage }\end{array}$} & 1-5year & 300 & 90.90 & $169.58 \pm 11.75$ & \multirow[t]{3}{*}{$\mathbf{P}<.001^{* *}$} & $112.45 \pm 12.89$ \\
\hline & $6-11$ & 10 & 3.03 & $168.37 \pm 11.75$ & & $85.25 \pm 11.85$ \\
\hline & $>12$ & 47 & 14.24 & $152.48 \pm 11.75$ & & $73.65 \pm 15.86$ \\
\hline
\end{tabular}

$\mathbf{P}<$.001 ${ }^{* *}$

$\mathbf{P}<$.01* 
Table 2. The relationship between marital commitment and level of sexual satisfaction

\begin{tabular}{|l|c|c|c|c|c|c|}
\hline Variable & $\begin{array}{c}\text { Lack of } \\
\text { sexual } \\
\text { satisfaction } \\
\mathrm{n}=7\end{array}$ & $\begin{array}{c}\text { Low sexual } \\
\text { satisfaction } \\
\mathrm{n}=37\end{array}$ & $\begin{array}{c}\text { Medium } \\
\text { sexual } \\
\text { satisfaction } \\
\mathrm{n}=148\end{array}$ & $\begin{array}{c}\text { High sexual } \\
\text { satisfaction } \\
\mathrm{n}=138\end{array}$ & \multicolumn{2}{|c|}{ ANOVA } \\
\hline $\begin{array}{l}\text { mean } \pm \mathrm{SD} \\
\text { commitment } \\
\text { Total }\end{array}$ & $110.83 \pm 14.65$ & $165.54 \pm 20.94$ & $180.98 \pm 21.75$ & $200.65 \pm 25.87$ & 24.241 & 0.001 \\
\hline
\end{tabular}

Recebido em 09/12/2020.

Aceito em 08/05/2021. 